\title{
On Semantic Model of Formative Assessment in Connection with Learning Ecosystem
}

\author{
Nguyen Manh Hung
}

\begin{abstract}
Nowadays, assessment for learning and formative assessment are key concepts for learning and teaching assessment, and have been received a huge interests both in scholarly study and practical application. Based on the idea that formative assessment has to embedded into learning environment and process, this paper is studying the combination of learning ecosystem and formative assessment, and suggesting a semantic model of this formative assessment using semantic technology.
\end{abstract}

Index Terms - Assessment for learning, formative assessment, learning ecosystem, Semantic technology.

\section{INTRODUCTION}

We are facing the biggie's challenge of transformation of education towards tremendous changing world today of digital and knowledge-based economy. One of the key elements of this transformation is an assessment.

Assessment for learning is an important concept for learning and teaching assessment recently. Beside of improvement of summative assessment, formative assessment has enormous interests both in scholarly study and practical application.

In terms of information technology implementation of learning analytics, it is widely applied the inBloom model and application for K12 in US [1]. The emerging e-learning standard XAPI (Tin Can API) [2] is also designed for storing all e-learning activities with the format of statement "I did this" from any learner at any time and anywhere.

Based on the idea that formative assessment has to embedded into learning environment and process, this paper is studying the combination of learning ecosystem as holistic learning environment and formative assessment, and using semantic technology for implementation of this formative assessment.

We will conduct a brief presentation of assessment for learning concept and associated concepts of formative and summative assessments, describe learning process based on learning activity over the learning ecosystem model, and lastly, introduce the semantic model of formative assessment in learning ecosystem.

\section{ASSESSMENT FOR LEARNING}

We are exposing the shift from teaching to learning as a learner is the centre of education, and therefore the

Manuscript received July 5, 2014; revised September 12, 2014.

Nguyen Manh Hung is with National Institute of Education Management of Vietnam, Vietnam (e-mail: hungnm@hnue.edu.vn). assessment of learning is moving to assessment for learning. This paradigm is stated by Black [3] published a precise but detailed definition of what can be described as

\section{A. Assessment for Learning}

"Assessment for learning is any assessment for which the first priority in its design and practice is to serve the purpose of promoting pupils' learning. It thus differs from assessment designed primarily to serve the purposes of accountability, or of ranking, or of certifying competence. An assessment activity can help learning if it provides information to be used as feedback, by teachers and by their pupils in assessing themselves and each other, to modify the teaching and learning activities in which they are engaged. Such assessment becomes 'formative assessment' when the evidence is actually used to adapt the teaching work to meet learning needs."

The phenomenon of this approach, that has been widely investigated for theoretical and practical embodiment in education, is based on the results of researches conducted by P. Black and D. Wiliam, [4], [5], which stated: "Innovations that include strengthening the practice of formative assessment produce significant and often substantial learning gains" ([5]).

This conclusion, from P. Black and Wiliam's comprehensive review of research on formative assessment practices [4], has changed the face of assessment today. It is in large part responsible for the widespread focus in education on the particular kind of assessment known as "formative".

In the last decade, there are numerous researches conducted to develop and implement this concept of formative assessment, e.g. J. M. Atkin et al. [6], J. Chappuis [7], Richard Stiggins [8], Wiggins Grant [9], etc. Recently the book of Seven Strategies of Assessment for Learning [7] provides a new structure for instructional strategy of formative assessment as organized research-based recommendations about formative assessment practices into an instructional framework that can improve student achievement.

\section{Formative ASSESSMENT VS. SumMATIVE ASSESSMENT}

We use the definitions from Seven Strategies of Assessment for Learning [7]:

\section{A. Formative Assessment}

Formal and informal process teachers and students use to gather evidence for the purpose of improving learning.

\section{B. Summative Assessment}


Assessments that provide evidence of student achievement for the purpose of making a judgment about student competence or program effectiveness.

Thus, formative assessment must involve in whole learning process or any learning activity in order to 1) collect and gather information of learning; 2) record and store this information into databases; 3) analyze these learning evidences for matching with learning target or objectives; 4) feedback or response to learners, teachers, stakeholders for adjusting/closing the gaps/improving learning or teaching:

"Assessment in education is the process of gathering, interpreting, recording, and using information about pupils' responses to an educational task" [10].

Margaret Heritage [11] has proposed the "Formative Assessment Model" as Fig. 1:

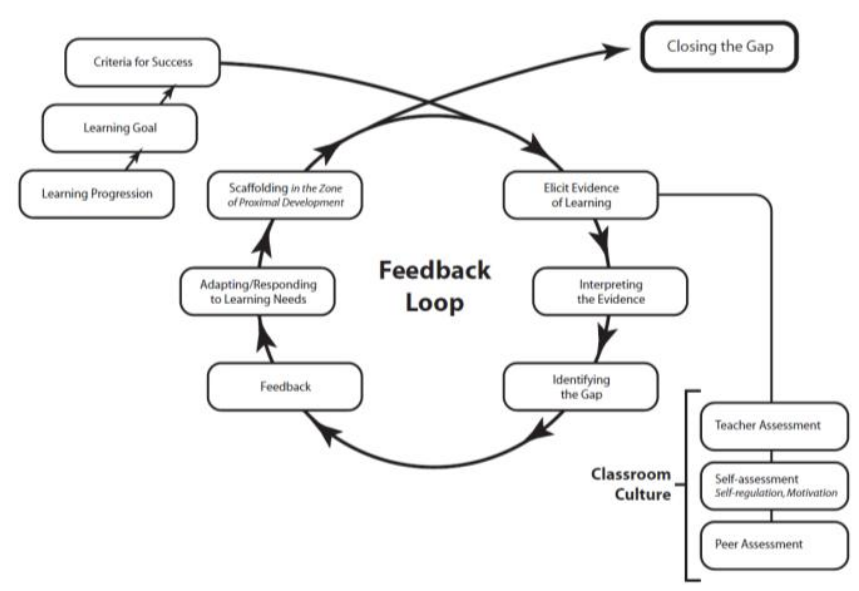

Fig. 1. Formative assessment model.

\section{LEARNING ACTIVITY IN LEARNING ECOSYSTEM}

Learning ecosystem is proposed by Nguyen Manh Hung [12] as a holistic ecosystem for nurturing and developing learning individuals, groups and networks, and detailed as integration of 4 components: Learning Actor (Subject), Learning Content, Learning Context and Learning Technology with structure as Fig. 2 (Nguyen Manh Hung, Nguyen Hoai Nam, [13]). This learning ecosystem concept is characterised by following:

- This is an environment for nurturing and developing learning individuals, groups and networks with interactions as sharing, creating own knowledge, exchanging learning knowledge and experiences inside and outside this ecosystem.

- Learning ecosystem may have other nested ecosystems within or is being nested within other ecosystems with interactions and connections.

- Learning ecosystem can be used for building learning environment for personal learner, group or network of learners and instructors for a given learning course or goal.

These four (04) components serve as a comprehensive environment for learning or teaching process in term of this learning ecology is provisioning necessary resources and environment for building and conducting activities for learning and teaching.

Based on this learning ecosystem structure, any learning process even formal or informal can described as a series of learning activities with semantic quad:

\section{Subject - Verb - Object - Adverb}

E.g. sentences:

Nguyen with a group of 3 pupils Nguyen, Tran, Pham | solved | the task No 10 in web http://www.math.task/ | today for an online math competition http://www.math.task/ in 1 hour in Facebook

Nguyen | reads | article about formative assessment at Wikipedia | as prerequisite for Lesson 1

Nguyen | compares | triangle and square at textbook Math1 in page 5 | for understanding the geometry lesson

These learning semantic quads in connection with assessment to form a learning activity model described in Table I.

\section{Subject - Verb - Object - Adverb <==== Assessment}

As mentioned in the formative assessment model, there are loops of gathering learning assessments for all learning activities and matching with a learning goal, evaluating progress, connecting with criteria of success for closing the gap.

Therefore, we can use above-mentioned semantic description of learning activities for gathering all learning assessment information into the stores. Then we can enable semantic rules and connections between entities of this model for analyzing the gathered assessment against targets or goals that set for each learning process for every student and teacher.

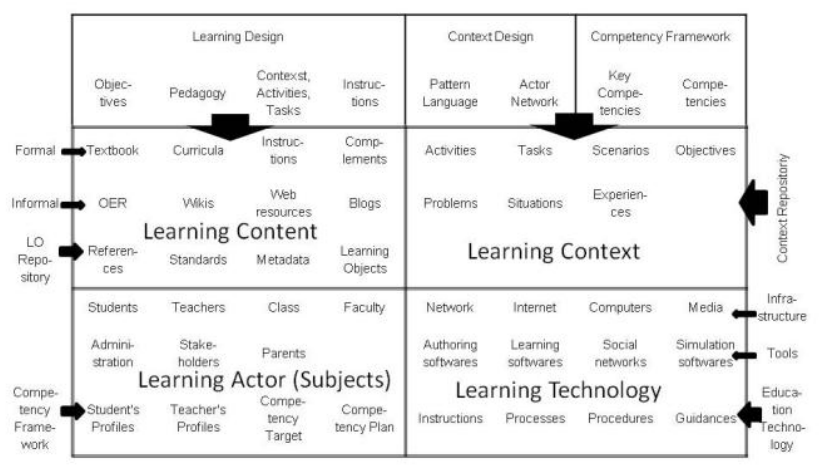

Fig. 2. Structure of learning ecosystem.

\section{Semantic Model of Formative Assessment IN LEARNING ECOSYSTEM}

The semantic model of formative assessment is based on following elements:

- Learning activity semantics (LAS): this is set of all semantic learning activities that described in above part.

Using RDF (Resource Description Framework) schemas for representing these LAS:

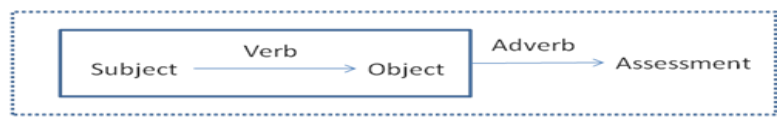

Learning Assessment Semantic (LAS)

Fig. 3. Learning assessment semantics RDF schema.

- Stores/Repositories of these learning activity semantics: SLAS

- Ontology Domains connect concepts of subjects, verbs, objects, adverbs and assessments. Below we can list as examples of these domains. 
TABLE I: LEARNING ACTIVITY SEMANTIC DESCRIPTION

\begin{tabular}{|c|c|c|c|c|}
\hline Subject & Verb & Object & Adverb & Assessment \\
\hline $\begin{array}{c}\text { The subject can be } \\
\text { student, teacher, } \\
\text { stakeholder, parents, } \\
\text { manager }\end{array}$ & $\begin{array}{l}\text { The learning verb can be } \\
\text { defined using Bloom } \\
\text { taxonomy of cognitive, } \\
\text { affective or } \\
\text { psychomotor domains }\end{array}$ & $\begin{array}{l}\text { Learning formal or informal } \\
\text { contents as lesson, text book, } \\
\text { online course, online wiki, } \\
\text { book, paper, assignments, } \\
\text { exercise, work, seminar, } \\
\text { meeting, discussion }\end{array}$ & $\begin{array}{l}\text { The context of learning } \\
\text { activity as where (class or } \\
\text { online URI), when, duration, } \\
\text { self-paced, networked, } \\
\text { grouped, using technology, } \\
\text { purpose or goal, objectives }\end{array}$ & $\begin{array}{c}\text { The assessment, evaluation as } \\
\text { teacher assessment, } \\
\text { self-assessment, } \\
\text { peer-assessment, evaluation, } \\
\text { mark, score, benchmark, } \\
\text { grade }\end{array}$ \\
\hline $\begin{array}{l}\text { Described as } \\
\text { list/tree/network of items, } \\
\text { each item has some } \\
\text { elements like: ID, name, } \\
\text { title, class, school, profile } \\
\text { id or URI }\end{array}$ & $\begin{array}{c}\text { Described as a } \\
\text { list/tree/network of } \\
\text { trio-verbs: cognitive, } \\
\text { attitude or value, skill, } \\
\text { that defined in Bloom } \\
\text { taxonomy }\end{array}$ & $\begin{array}{l}\text { Described as list/tree/network } \\
\text { of items, each item has some } \\
\text { elements as ID, name, title, } \\
\text { URI or course book, place }\end{array}$ & $\begin{array}{c}\text { Described as a serie of items, } \\
\text { each items has some attitudes } \\
\text { like time, place or URI, } \\
\text { condition, situation, } \\
\text { technology, learning goal or } \\
\text { objective }\end{array}$ & $\begin{array}{c}\text { Described as a list of } \\
\text { assessment value or } \\
\text { measurement, like score, } \\
\text { mark, attitude, skill level, } \\
\text { emotion }\end{array}$ \\
\hline $\begin{array}{l}\text { Using recourses from } \\
\text { Learning Subjects }\end{array}$ & $\begin{array}{l}\text { Using recourses from } \\
\text { Learning Context }\end{array}$ & $\begin{array}{l}\text { Using recourses from } \\
\text { Learning Content }\end{array}$ & $\begin{array}{l}\text { Using recourses from } \\
\text { Learning Context and } \\
\text { Learning Technology }\end{array}$ & $\begin{array}{c}\text { Assessment (score, mark, } \\
\text { attitude, self-evaluation, } \\
\text { peer-evaluation). }\end{array}$ \\
\hline $\begin{array}{c}\text { Student A - URI } \\
\text { http://www.hnue.edu/e-pr } \\
\text { ofiles/a }\end{array}$ & $\begin{array}{l}\text { Identify, compare, } \\
\text { design }\end{array}$ & $\begin{array}{l}\text { Examples } \\
\text { Homework exercise 10 at URI } \\
\text { http://www.hnue.edu/hungnm } \\
\text { /comnet/lesson1/exercise10 }\end{array}$ & $\begin{array}{l}\text { At home, chatting with teacher } \\
\text { for help if needed via } \\
\text { Facebook, for understanding } \\
\text { network topology }\end{array}$ & Score: $\operatorname{good}(04)$. \\
\hline Group 1 (Student A, B, C) & $\begin{array}{l}\text { Select, plan, solve, } \\
\text { present }\end{array}$ & $\begin{array}{l}\text { Assignment } 1 \text { at URI } \\
\text { http://www.hnue.edu/hungnm } \\
\text { /comnet/lesson2/assigment1 }\end{array}$ & $\begin{array}{l}\text { Collaborating thru facebook } \\
\text { and Viber, due before } 12 \text { noon } \\
\text { tomorrow }\end{array}$ & Score: excellent (05). \\
\hline $\begin{array}{c}\text { Student D URI } \\
\text { http://www.hnue.edu/e-pr } \\
\text { ofiles/d }\end{array}$ & $\begin{array}{l}\text { Attend, identify, } \\
\text { describe, explain }\end{array}$ & Lesson Math of Dr. E & At room 104 on Mar-2-2014 & $\begin{array}{l}\text { Good understand. Attitude: } \\
\text { good. Self-Evaluation: boring }\end{array}$ \\
\hline
\end{tabular}

Domain Subject with sub domains such as Name, Student Information, Previous Assessment Levels, ID, etc.

Domain Verb with sub domains such as Cognitive, Affective, Psychomotor.

Domain Object with sub domains such as Name of Content, Title, Owner, URI, Description, Prerequisite, Place, Pedagogy, Type of Content, Knowledge Dimension, et al.

Domain Adverb with sub domains such as Pattern of Context, Objective, Goal, Time, Duration, Connection Type, et al.

Domain Assessment with sub domains such as Formal, Self Assessment, Peer Assessment, Mark, Notes, Score, Benchmark, Cognitive Level, Attitude, Value, Skill Level, et al.

- Ontology rules set for connecting concepts together for analyzing LAS to build students' assessments and matching with learning and teaching goals/objectives, which are built on competency standard/framework.

- This loop ends with feedback to learning ecosystem for improving the teaching and learning process. This feedback or response process can be executed online via technology tools such as email, SMS, Facebook, Twitter, Skype, LMS or off-line via meetings or discussions.

In general, the semantic model of formative assessment can described as follow:

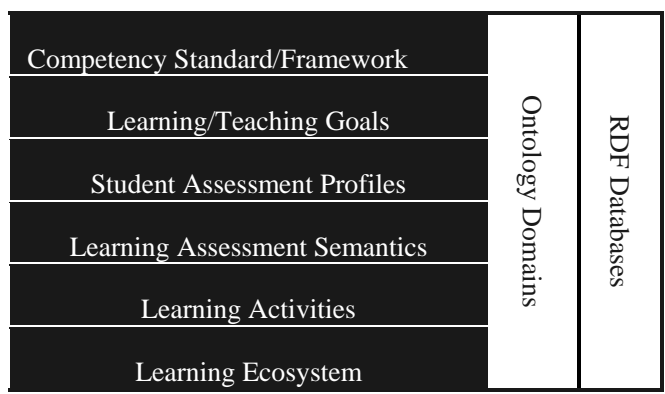

Fig. 4. Semantic assessment model
This model can be setup in information technology system using semantic technology such as RDF schema, ontology and data mining techniques.

\section{CONCLUSION}

From the idea of a new model for support formative assessment implementation using information technology, we are trying start from learning ecosystem as practical perspective of comprehensive environment for learning/teaching to suggest the semantic model of learning assessment based on semantic technology.

The paper reserves the part of designing ontology sets of this model as open for further study.

\section{REFERENCES}

[1] In Bloom Project Document. (2014). Learning Standard Alignment in inBloom Technology: A Whitepaper. [Online]. Available: https://www.inbloom.org/sites/default/files/learning-standards-alignm ent_0.pdf.

[2] Advanced Distributed Learning Initiative. (2013). U.S. Department of Defense. Experience API Specification v.1.0.0. 2013. [Online]. Available: https://github.com/adlnet/xAPI-Spec.

[3] Paul Black. (2004). The Nature and Value of Formative Assessment for Learning. The King's College London Assessment for Learning Group. Draft. [Online]. Available: http://www.stivoschool.org/L_T/files2/The\%20original\%20Black\%2 0and\%20Williams\%20paper\%20on\%20Formative\%20Assessment.pd $\mathrm{f}$

[4] P. Black and D. Wiliam, "Assessment and classroom learning," Assessment in Education, vol. 5, no. 1, pp. 7-74. 1998

[5] P. Black and D. Wiliam, "Inside the black box: Raising standards through classroom assessment," Phi Delta Kappan, vol. 80, no. 2, pp. 139-148, 1998.

[6] J. M. Atkin et al., Classroom assessment and the National Science Standards, Washington, DC: National Academy Press, 2001.

[7] J. Chappuis, Seven Strategies of Assessment for Learning, Portland, OR: ETS Assessment Training Institute, 2009.

[8] R. Stiggins, J. Arter, J. Chappuis, and S. Chappuis, "Classroom assessment for student learning: Doing it right — Using it well," Portland, OR: ETS Assessment Training Institute, 2004.

[9] G. Wiggins, Educative Assessment, San Francisco, CA: Jossey Bass, 1998. 
[10] W. Harlen, C. Gipps, P. Broadfoot, and D. Nuttall, "Assessment and the improvement of education," The Curriculum Journal, vol. 3, pp. 215-230, 1992.

[11] Margaret Heritage. (2007). Model of Formative Assessment. Assessment and Accountability Center (AACC)/National Center for Research on Evaluation, Standards and Student Testing (CRESST) at University of California Los Angeles. [Online]. Available: http://www.nycomprehensivecenter.org/docs/form_assess/ModelofFo rmativeAssessment.pdf.

[12] Nguyen Manh Hung, "Using ideas from connectivism for designing new learning models in Vietnam," International Journal of Information and Education Technology, vol. 4, no, 1. pp. 76-82, 2014.

[13] M. H. Nguyen and H. N. Nguyen, "On the procedural structure of learning ecosystem toward competency learning model," Journal of
Science, Hochiminh City University of Education, vol. 53, no. 87, pp. $13-23,2013$.

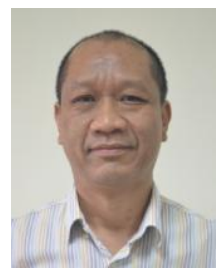

Nguyen Manh Hung is a lecturer at National Institute of Education Management, Vietnam. He held a PhD in physics-mathematics at State University of Chisinau, Moldova in 1991. His main reseach interests are e-learning and computer network. 